\title{
Peasant Revivalism and Secularization: Protestant Popular Culture in Denmark and Sweden 1820-1850
}

Hanne Sanders

Follow this and additional works at: https://scholarsarchive.byu.edu/thebridge

Part of the European History Commons, European Languages and Societies Commons, and the Regional Sociology Commons

\section{Recommended Citation}

Sanders, Hanne (1999) "Peasant Revivalism and Secularization: Protestant Popular Culture in Denmark and Sweden 1820-1850," The Bridge: Vol. 22 : No. 1 , Article 7.

Available at: https://scholarsarchive.byu.edu/thebridge/vol22/iss1/7

This Article is brought to you for free and open access by the Journals at BYU ScholarsArchive. It has been accepted for inclusion in The Bridge by an authorized editor of BYU ScholarsArchive. For more information, please contact scholarsarchive@byu.edu, ellen_amatangelo@byu.edu. 


\title{
Peasant Revivalism and Secularization: Protestant Popular Culture in Denmark and Sweden 1820-1850
}

\author{
by Hanne Sanders
}

The subject of this dissertation is religious revivalism in Danish and Swedish agrarian society in the first half of the nineteenth century. Its purpose has been to analyse a specific religious phenomenon in a presecularized society. As other historians have done, I have analysed revivalism from a social and a political point of view. Furthermore, I have focused on the religious dimension of the movement not as a theological, but as a cultural and social problem. My main thesis is that during the secularization of society the meaning of religion changed from knowledge and social culture it came to mean an individual and existential belief.

In taking religion to be a popular world picture, my research can be seen as cultural history in the modern sense of the word. Furthermore, I align myself with modern criticism of much cultural historiography. I too think that it has been too structuralistic in its purpose, too eager to find one popular culture holding good in Europe between 1500 and 1800 , too ready to stress the oppositional character of this culture to an elite culture. I do not think that it is possible, or even interesting, to draw such a clear dividing line between popular and elite culture. Their relationship has changed during history, and cultural elements have always transfered from one type of culture to another. Often parts of a previously elite culture have gone on to be used in popular culture. This dialogue will probably always exist, and therefore it is not possible to find a "pure and unsullied" popular culture. From this follows my second objection to the structuralist conception of popular culture. It is perhaps possible to find some common elements in popular cultures in all areas of Europe over the course of three hundred years, but there will always be differences in how people used these cultural forms, and such usage will be mixed with a lot of more specific elements. From my point of view the interesting thing is to know how all elements of a popular culture functioned together, and how it was related to contemporary elite culture.

Danish and Swedish revivalism in the first half of the nineteenth century was not a popular movement in the usual sense of the word. 
It was not formally organized as a Free Church or as an organization within the two official churches. Furthermore, it was not uniform throughout the countries. In the south-western part of Sweden it tended to be people who did not want to use their own clergyman but chose another to whom they were prepared to travel to attend his sermons or for whom they wrote letters of support. Especially on the Danish islands, one finds revivalism centred on revival meetings in the supporters' houses. I term this conventicle revivalism. In northern Sweden one finds a fairly similar movement, the exception being that the revivalists did not only preach to one another but also administered sacraments such as baptism and Communion. In both northern and western Sweden there was an ecstatic movement called "roparna" ("the shouters"). They too arranged revival meetings, but during their sermons the preachers were racked with cramps and finally fainted, and, when they awoke, related their religious experiences to the congregation. Meanwhile, in eastern Sweden, in the region around the Lake Mälaren, in most parts of Östergötland, and in large areas of the Danish peninsula of Jutland, there was no revivalism at all.

This is the received picture of revivalism among scholars. In my research I have found at least one exception to this. In parts of western Sweden, a form of revivalism existed that was led by clergymen as well as the laity. In other words, as in Denmark and northern Sweden, there was conventicle revivalism here, too.

It is difficult to find the common denominator of all these manifestations of the revivalist movement. In my opinion there are three important characteristics: firstly, the movement centred on religious questions; secondly, it created conflict among people in society; and thirdly, it was a social phenomenon and not merely a matter of individual conflict. This definition of revivalism differs from the theological one, which stresses the personal, pietistic experience of rebirth. Furthermore, I find it unhelpful to make use of sociological or psychological definitions because they try to give an opinion on the content of revivalism. In that, they often depart from modern concepts of religious belief or organization. I aim to show what the actual religious conflict was about, and from where the supporters of the movement drew the strength to fight.

By using this perspective, it has been possible to arrive at a model that embraces all types of revivalism. This emanates from my analysis of what I have called the official world picture. This is expressed in the ecclesiastical legislation between the end of the seventeenth century and the end of the nineteenth century. Basically, there was only 
one way to understand the religion. That was to follow the true word of God. There were no possibilities for personal interpretation, and it made no sense to argue for the right of different clergymen to have different ways of reading the Bible. In every church all over the country, the same true word of God was to be presented without exception. It was a typically pre-secularized world picture. Consequently, many social issues were organized from this starting point, such as education, working-hours, immigration, the local judical system, national registration, an attempt to gather national statistics, and the fundamental ideas of countries' scientists.

All types of revivalism challenged this official world picture, but they did it to different degrees. Revivals led by clergymen challenged authority only by instigating choice among clergymen, and not by denying that clergymen were the only possible interpreters of the word of God. The challenge to the clergymen's monopoly on preaching came from the conventicle revivals. A still greater challenge was presented by the revivalists who even tried to take over the role of administering the sacraments. The greatest challenge of all was posed by those who tried to abandon the official church, which in the old world picture was meant to be for all people. In this thesis I have analysed the two first steps or degrees of challenge, bearing in mind that remaining two only were only further developments of the first two.

The problems associated with definition originate partly in the fact that, to a great degree, research into revivalism has been limited to a national level. Nobody has been interested in features common to Danish and Swedish revivalism. This is a failing, especially because revivalism of this non-organized type was common all over the Protestant world in the first half of the nineteenth century. My study of two Nordic revivalist movements is therefore a case study of a Protestant, European phenomenon.

I have chosen two areas for my investigation: the western Swedish diocese of Skara; and the Danish island Langeland. From these, I gathered many examples of western Swedish revivalism led by clergymen, conventicle revivals in both areas, and "roparna" in the Swedish district. Several Swedish scholars have suggested that the movement led by the laity was confined to the wooded districts, whereas the movement led by clergymen predominated in the flat, open country. I, on the contrary, find no such distribution; all sorts of revivalism were found in both wooded and open districts. This confirms my thesis that the differences between these two types of revivalism are only differences of degree. 
I have divided my analysis into three parts. Firstly, I have analysed what is called the social profile of revivalism (Chapter 5). Secondly, I have discussed the forms of activity and organization, the political culture of revivalism (Chapter 6). Thirdly, the movement is seen against the wider world picture, and revivalism is put in context as a Protestant popular culture (Chapter 7).

Chapter 5, concerning the social base of revivalism, starts from the fact that for Danish and Swedish agrarian society the century between 1750 and 1850 was one of extreme change. Peasants bought their own land and began to sell agrarian products on domestic and international markets. Agricultural techniques were improved in many different ways, although naturally not all peasants benefited from these improvements at first. The agrarian proletarian group grew rapidly. The revivalism I have studied appeared exactly in the middle of these developments, and for that reason it makes sense to see it as a movement for the winners as well as for the losers in the great agrarian revolution. In former research, one finds both perspectives, but the most common line among modern historians is either to underline the proletarian character of revivalism, or to typify it as a movement for young people in opposition to the older generation.

My conclusions differ from this considerably. For all types of revivalism I find that the peasants were the most important group. They were not in majority, but they played central roles. They were the most common hosts for the religious meetings. They acted in support of prefered clergymen, in most cases with the aim of getting him for their own parish. Among the supporters you find quite a lot of young people, and that is the reason why scholars have tried to explain the movement as a conflict between generations. When you examine the social relations between the supporters you find, however, that all young people can be connected with older, socially established supporters of revivalism, either as children or as servants.

The result of agrarian development was to be very different in the areas under study. In the western Swedish area, freeholders became an overwhelming majority among peasants, while on the Danish island of Langeland, peasants continued to live as tenant farmers as they had always done. I show that the question of landownership was not important. The main thing was that the peasants dominated both economy and culture, and that this was not challenged by estate owners or by non-agrarian production. Nor was the degree of proletarization important as long as the poor lived in a peasant-dominated economy and culture. A common feature of the areas studied was the importance of new agricultural technology and of market 
integration. A peasant-dominated culture in the setting of dynamic agrarian development was a fruitful environment for revivalism.

This perspective is further developed by analysing women in revivalism. It is common among Anglo-Saxon historians to emphasise the fact that women found a special place in revivalism because it was emotionally charged and was concerned with the problems of the household. I too find many revivalist women, but this was not because of any especially feminist character. The reason why women as well as men were active in revivalism was that it was built on elements of traditional society where men and women did not have segregated places. Religion was for all people, and the Church had directed its education to all. As I show later, the household was the basic unit of revivalism. In this smallest economic and social organization of the old agrarian society, men as well as women had their place. In the beginning of the nineteenth century, household matters were not reserved for women, but were important to men too. At the same time, it was quite normal for men to exhibit emotional behaviour. The bourgeois notion of women as working at home and being emotional had yet not developed.

The question posed in Chapter 6 about the political culture of revivalism is how best to characterize the organization of revivalism when you can not describe it as a popular movement in the traditional sense of the word. In revivalism, there was no organization to be a member of. It centred on the relationship between a speaker and his listeners, and this relationship existed only at a religious ceremony. It could be the clergyman's service in the church, or the lay preacher and his conventicle in an ordinary house. Relations between the revivalists were emotional. The arguments in favor of starting the spiritual struggle were individual needs and emotions. In this sense, you can talk about revivalism as a modern, bourgeois, political culture stemming from the individual principle of one man one voice.

In order to get closer to the organization, I have examined how revivalism was spread, and what held it together. In doing so, one finds parts of the answer to the question of why not all peasant-dominated areas where there was agrarian development took to revivalism. I have stressed two important elements. The first was the network of the supporters. Revivalism was spread by word of mouth, and participants in the religious meetings are often said to be neighbours. Another important network was the family or the household. Revivalism was spread in the locality through the agency of neighbours, but through a family's, or a household's, kith and kin it could spread much further. In addition, it is evident from the exami- 
nation of the social profile of revivalism how important the household was for local recruitment. Finally, the revivalists tried to make their conventicles ideologically legitimate by refering to generally accepted devotions of the household led by the head of the household. I therefore term all revivalist movements of the laity household revivalist movements.

The second element was the importance of the leaders for how revivalism was spread and how it was held together. The lay preachers from a revivalist area walked to a new area to spread the message. Clergymen circulated, but not as a result of their own wishes; on the contrary, it was because, in order to stop revivalism, the bishop sent them away from the parish where they had supporters to new parishes. The result was the same. More people came into contact with revivalism.

I have discussed whether Max Weber's idea of a charismatic leadership is useful in understanding the preacher's role in revivalism. My conclusion is negative. It is true that the emotional element was important for the solidarity of revivalism, in the same way that contact with God showed the legitimacy of the preachers. At the same time, revivalism used many traditional organizing principles. It was bound up in two of the oldest organizations in agrarian society: the church and the household. Both had powerful leaders, who instilled great respect in the movement's supporters by behaving like the clergymen of the old system. Revivalism included modern or charismatic elements as well as traditional ones, and if one uses the Weberian concept, one can not understand this dynamic interplay between modernity and tradition, which was exactly what gave revivalism its strength.

As for the conflict-shaping activities of revivalism, they all took as their basis the individual and his right to decide his own religious life. That said, there were differences between the revivalist movements studied here. In the western Swedish area, revivalists were not as keen to challenge authority as those on the Danish island. They tended to the less challenging type of revivalism, the one led by clergymen, and when leading it themselves, they quickly gave up when they met with opposition. In Denmark, however, a meeting in the courtroom, an obvious manifestation of the revivalist's conflict with the authorities, was seen as the best occasion for a religious meeting by the accused and his supporters.

I explain this by the fact that the Swedish peasants had an old tradition of local self-government. They had responsibility for many local affairs, among others the election of clergymen. They had influ- 
ence on national matters, too, and generally, you can say that, compared with Danish peasants, they had an old and formally organized political culture to use. This political culture had a conservative effect on revivalism. The Swedish revivalists only wanted to do what they had a right to do. In Denmark, the peasants might have had the same ambition, but they had no political culture either to use or to be restricted by. That is why they created a new political culture, which was provocative and more modern than the Swedish.

Finally, in Chapter 7, I have analysed the world picture of the members of the revivalist movement. Here again, one finds two groups of historians at work, one that stresses the new, individualistic elements critical of the state system, and one that stresses the opposite, that is to say, allegiance to the state. As in Chapter 6, my main thesis is that revivalism was actually a mix of both, and that this is of extreme importance in understanding the movement.

I have found three types of argument used by revivalists at that time. They find authority for their activities in the Bible; in describing their everyday life they make liberal use of Biblical quotations. The words of Jesus to his disciples were thought of as words to the revivalists themselves. And the activities of the apostles were compared with those of the revivalists. In their conflict with a local Danish official, the main issue was that they could not accept his opinion that the content of the Bible depended upon the reader or the interpreter. According to the revivalists, the eternally true word of God was to be found in the Bible. That being so, everybody was able to read and use the Bible, and they saw no reason for preserving the clerical monopoly. This dependence on the Bible was fundamental in the official world picture and in Protestant ideology as a whole. The supporters of revivalism built their arguments on a common, and truly Protestant basis. At the same time, the Bible gave them useful roles to imitate.

Their second argument was that they did what they had to do to secure their salvation. Behind this lay a dualist world picture with a clear conflict between God and the Devil. They fought for men's souls. Every man belonged to one of them, and everything could be explained as being either from God or from the Devil. There is little place for individual, human influence. In order to avoid Hell, all you could do was to give youself to God and believe in Him. Again, there is a very basic Protestant idea at the bottom of the revivalists' argument. It could be expected that this idea did not motivate the revivalists to act, but this was in fact the case. As a sort of parallel to the Weberian idea of the meaning of Protestant ethics for capitalism, I have found people 
acting not in order to be saved, but rather to show that they belonged to the men of God, the Blessed.

The last argument was that the revivalists behaved only as could be expected of Christian subjects of a Christian state. Again, in a very Protestant way, and by using biblical quotations, they anxiously expressed their acceptance of the authorities appointed by God. They used an argument popular during the Reformation; one should render to God what is God's, but at the same time render to Caesar what is his due. Earlier, the second clause had been the important one; now they stressed the first. The secular authorities only had the right to demand what was theirs, and that did not include the relations between the revivalists and God.

The provocative nature of revivalism did not originate in these traditional elements, even though they often were more old-fashioned than that which was asserted by the elite. Often you can even see elements of an older, elite culture emanating from the Reformation. It was the modern and secularized features that were provocative: the individual reading of the Bible and their placing themselves as arbiters of what was right and wrong; their assertion that individual salvation was a matter only for the individual. This was most evident in a couple of conflicts about Communion. Revivalist clergymen were spokesmen for the principle that everybody should decide themselves when and how often they would take Communion. This principle was of concern to men as well as women. It ran against the recommendation given in the ecclesiastical legislation that you should not take Communion more than once a year, and it was opposed by many other clergymen and the bishop. In this case the offending clergyman was punished by being suspended.

Revivalism had the strength to give a distinctive stamp to this secularized and modern concept of religion by stressing traditional elements in a religious world picture. God's word was the best safety net that one could wish for. In this fundamentalist and dualist conception of the world, the revivalists were more traditional than many of their contempories. They used Protestantism in their own way, and this created conflict. That is why I see this movement as a popular, Protestant culture typical of the first half of the nineteenth century. Using a more structuralist conception of popular culture, one would never have discovered this popular use of older Protestant elite culture, nor this important interplay between traditional and modern elements typical of revivalism in the first half of the nineteenth cen- 
tury. One would never have discovered the dynamic of this popular culture.

Generally, one can say that revivalism emerged at a time full of change. The revivalists experienced the beginnings of capitalist society, with individual ownership and a market economy, of a bourgeois political culture, and of secularized freedom of religion. They were met by the economic, political and religious individualism of the nineteenth century. They cried, "Stop!" And because they grew up in a pre-secularized society, they did it in religious language. By this individual action, they themselves expressed an individualist political culture and an individualist understanding of religion. Revivalism was therefore one of the many means by which modern society was built. And from revivalism it is possible to get information about the social, political and cultural possibilities for agrarian people living at a time that saw the dawn of modern society. In some places, as in Denmark, the development was faster and revivalism more powerful. Elsewhere, the pace was slower and revivalism was not so powerful. Revivalism shows, however, that irrespective of the speed of development, modern society was not the result of a sudden break with the past but arose through a dynamic interplay between elements old and new, traditional and modern. 